\title{
Memorandum Svazu Čechů-židů v Republice československé postoupené vládě během přípravy národnostního statutu $v$ roce 1938
}

\author{
Andrej Sulitka
}

Etnologický ústav $A V \check{C} R$, v. v. $i$.

Kontaktni e-mail: sulitka.andrej@seznam.cz

\section{Blanka Soukupová}

Fakulta humanitních studii UK

Kontaktnie-mail: 644@mail.fhs.cuni.cz

\begin{abstract}
Memorandum by the Union of Czech Jews in the Czechoslovak Republic submitted to the Government during Preparation of the Nationality Statute in 1938
\end{abstract}

\begin{abstract}
:
The number of suggestions submitted to the government by the representatives of ethnic minorities during preparation of the nationality statute in 1938 included one enterprisingly submitted by a Jewish union. The authors analyse the Memorandum prepared by the Union of Czech Jews in the Czechoslovak Republic, the highest institution of the Czech Jewish assimilationist movement. Although we do not have a response from government bodies to this document, we can state that it reflected the strong self-confidence of the Czech Jewish movement and simultaneously its exceptional loyalty to the Czech nation and the Republic. The Memorandum also demonstrates the permanent optimism of the movement, which continued in its sharply defined stance against the rival Zionist movement. The awareness of the danger to the republic evidently overrode the awareness of the danger to the Jewish minority. The Czech Jewish movement based its reasoning on sources from the last decade of the 19th century, the corner stone of which was the Czech Jewish understanding of the term "nation", which combined the traditions of Judaism, enlightenment and romanticism. A new aspect was the willingness of the Czech Jewish movement to cooperate with orthodoxy, while its efforts to present its own reasoning as being in the state and national interest and its abiding trust in the institution of the state were "traditional".
\end{abstract}




\title{
Keywords:
}

Jews; national minorities; interwar Czechoslovakia; nationality statute; Memorandum by the Union of Czech Jews (1938)

\begin{abstract}
Klíčová slova:
Židé; národnostní menšiny; meziválečné Československo; národnostní statut; Memorandum Svazu Čechů-židů (1938)
\end{abstract}

DOI: $10.14712 / 2464689 X .2018 .43$

Financování: Př́íspěvek byl zpracován s institucionální podporou Etnologického ústavu AV ČR, v. v. i., RVO 68378076 (Andrej Sulitka), a v rámci grantového projektu NAKI II DG18P02OVV64 Právní, historické a společenskovědní aspekty nových a tradičních menšin v České republice (Blanka Soukupová).

Léta 1936 až 1938 jsou v české historiografii hodnocena jako zápas o přežití první masarykovské republiky. ${ }^{1}$ Hlavním motivem protičeskoslovenské německé kampaně se již v roce 1937 stal sudetoněmecký problém. ${ }^{2}$ V únoru 1938 pak Adolf Hitler, vůdce tzv. třetí ř́íše, veřejně deklaroval zničení Československa připojením pohraničí s většinovým německým obyvatelstvem k Německu. Konec mladého státu předznamenal i anšlus Rakouska v březnu téhož roku. V ovzduší „,smrtelného nebezpečí “ pro republiku československá vláda prohlásila, že připraví národnostní statut. S jeho pomocí se Československo mělo transformovat z národního státu ve stát národnostní. Zoufalý pokus zachránit stát vypracováním nové menšinové politiky však narazil na odmítnutí sebevědomé Henleinovy Sudetoněmecké strany, pod jejímž vlivem byla v této době již většina československých Němců. ${ }^{3}$ Úlohou tohoto politického subjektu se stalo vyhrocování národnostních konfliktů, které mělo umožnit diplomatickou a vojenskou intervenci nacistického Německa. ${ }^{4}$

Otázce prŕípravy návrhu na vydání národnostního statutu byla věnována pozornost v celé řadě prací. Po roce 1989 obohatily stávající literaturu k tomuto tématu především dvě rozsáhlé monografie. ${ }^{5} \mathrm{~V}$ monografii Andreje Tótha, Lukáše Novotného a Michala Stehlíka byly zmapovány základní kroky vedoucí k vydání národnostního statutu. Autoři upozornili na tu skutečnost, že právní úprava národnostní otázky byla zahájena 18. března 1938 vydáním vládního memoranda. K již existujícímu vládnímu usnesení z 18. února předchozího roku tak měla přibýt kodifikace menšinových práv. ${ }^{6}$ Politickým

1 Viz např. KÁRNÍK, Z. České země v éře Prvni republiky (1918-1938). Díl třetí. O prežití a o život (1936-1938). Praha: Nakladatelství Libri, 2003.

2 OLIVOVÁ, V. Dějiny první republiky. Praha: Karolinum, 2000, s. 218.

3 Souhrnně viz BĚLINA, P. - POKORNÝ, J. (red.). Dějiny zemi Koruny české II. Praha: Paseka, 1992 , s. 186.

4 Srov. Konfliktni společenství, katastrofa, uvolněni. Náčrt výkladu česko-německých dějin od 19. století. Praha: Ústav mezinárodních vztahů, 1996, s. 20.

5 NOVOTNÝ, L. - STEHLÍK, M. - TÓTH, A. Národnostní menšiny v Československu 1918-1938. Od státu národniho ke státu národnostnímu? Praha: Togga, 2012; KUKLÍK, J. - NĚMEČEK, J. Od národního státu ke státu národností? Národnostni statut a snahy o řě̌ení menšinové otázky v Československu v roce 1938. Praha: Karolinum, 2013.

6 Srov. KLIMEK, A. - KUBU゚, E. Československá zahranični politika 1918-1938. Kapitoly z dějin mezinárodnich vztahů. Praha: Institut pro středoevropskou kulturu a politiku, 1995, s. 83; KUKLÍK - NĚMEČEK, 
spojencům Československa (Francii a Anglii) bylo memorandum postoupeno 26. dubna. Československá vláda nárys rámcového programu schválila 19. května. ${ }^{7} 28$. července byl program postoupen Sudetoněmecké straně, jež se k němu ovšem negativně vyhranila již na dubnovém sjezdu v Karlových Varech, ${ }^{8}$ kde podle Ferdinanda Peroutky, šéfredaktora týdeníku Př́ítomnost, blízkému politické linii Hradu, přednesl Konrad Henlein výbojnou pangermánskou řeč, ${ }^{9}$ a v květnu ho německá strana odmítla. ${ }^{10}$ Podle Jana Kuklíka a Jana Němečka tak byla komplexní úprava právních otázek souvisejících s postavením menšin od počátku v krajně složité mezinárodní i vnitřní politické situaci odsouzena k nezdaru. ${ }^{11}$ René Petráš k tomu dodává, že němečtí experti současně vypracovali memorandum (tzv. Skizze), které postoupili vládě 7. června, což podle československých právních odborníků bylo v příkrém rozporu s ústavou. Profesora Františka Weyra Skizze přivedla k závěru, že jednání se Sudetoněmeckou stranou není možné. ${ }^{12}$ A jak napsala historička Věra Olivová: „Hlavním cílem Henleinovy strany bylo otevřít nacistickému Německu dveře do Československa."13 Jan Kuklík a Jan Němeček však zároveň upozornili na tu skutečnost, že se v atmosférée prríprav národnostního statutu přihlásili se svými vlastními požadavky také př́śslušníci domácího sionistického (poslanci Angelo Goldstein a Chaim Kugel, v roce 1935 zvoleni za Židovskou stranu do Národního shromáždění14) a asimilantského českožidovského hnutí. ${ }^{15}$

V memorandu vypracovaném Svazem Čechů-židů v Republice československé, vrcholným orgánem českožidovských asimilantů, se přitom podle jejich interpretace tvrdilo, že Židé netvoří vlastní národnost. V této souvislosti Jan Kuklík s Janem Němečkem správně podotkli, že zvláštní požadavky českožidovského hnutí (zřízení rabínského státního učiliště, dozor nad židovskými náboženskými obcemi, schválení Ústavy nejvyšší rady židovské, boj proti antisemitismu a podpora asimilace Židů na Slovensku a na Podkarpatské Rusi) by skutečně bylo možné zapracovat do připravované legislativní úpravy

c. d., s. 36. Podnětem ke kodifikaci menšinových práv byla mj. takzvaná dohoda uzavřená mezi československou vládou a německými aktivistickými stranami, které byly v této době zástupci již pouze o něco více než pětiny německého obyvatelstva. Návrh Sudetoněmecké strany požadoval ,sudetoněmeckou autonomii a uznání národní skupiny sudetských Němců za korporaci s veřejným právem a jednotným zastoupením“ - viz podrobněji OLIVOVÁ, c. d., s. 220.

7 Nejpozději o několik dnů později (30. května) padlo rozhodnutí Adolfa Hitlera rozbít Československo vojensky. Srov. Konfliktní společenství, c. d., s. 20.

8 NOVOTNÝ - STEHLÍK - TÓTH, c. d., s. 400, 401, 407-409, 412, 478-580.

9 SOUKUPOVÁ, B. Český sebevědomý sen a evropská realita. Reflexe Německa, Rakouska a českých Němcủ $v$ české demokratické společnosti první republiky. Č́st II: 1933-1938. Praha: Sofis, 2001, s. 129.

10 KURAL, V. Konflikt misto společenstvi? Čěsi a Němci v Československém státě (1918-1938). Praha: R ve spolupráci s Ústavem mezinárodních vztahů, 1993, s. 174-175; KÁRNÍK, c. d., s. 512; OLIVOVÁ, c. d., s. 232 .

11 KUKLÍK - NĚMEČEK, $c . d$., s. 55.

12 PETRÁŠ, R. Menšiny v meziválečném Československu. Právní postavení národnostních menšin v první Československé republice a jejich mezinárodněprávni ochrana. Praha: Karolinum, 2009, s. 259.

13 OLIVOVÁ, c. d., s. 231. Obdobně konstatoval historik Tomáš Pasák, že: „Dohodu... SdP nepotřebovala, nebot’ skutečná činnost henleinovců směřovala k rozbití republiky.“ Viz PASÁK, T. Český fašismus 1922-1945 a kolaborace 1939-1945. Praha: Práh, 1999, s. 201. Také Ferdinand Peroutka charakterizoval henleinovskou stranu jako „pangermanistickou zálohu pro př́pad války s Německem“, a to již v březnu 1936 v Lidových novinách. Viz SOUKUPOVÁ, Český sebevědomý sen, s. 118.

14 PĚKNÝ, T. Historie Židů v Čechách a na Moravě. Praha: Sefer, 2001, s. 138.

15 KUKLÍK - NĚMEČEK, $c$. d., s. 118. 
jen velmi obtížně. ${ }^{16}$ Hlavní osobností českožidovského hnutí, která se obracela dokonce prostřednictvím dopisů na předsedu vlády Milana Hodžu a kancléře Přemysla Šámala, se při vyjednávání o národnostním statutu stal JUDr. Otto Stross, ${ }^{17}$ tehdejší předseda Svazu Čechů-židů (1900-1941, Buchenwald). Dodejme, že nevíme, kdy se reprezentace Svazu Čechů-židů rozhodla zpracovat podněty $\mathrm{k}$ návrhu národnostního statutu, určitým vodítkem však může být zmínka v úvodu k memorandu, že se podání zdrželo, protože spolek očekával z předsednictva ministerské rady přislíbený podklad (svůj př́ípis zaslal 21 . května, žádost osobního tajemníka ministerského předsedy o písemné podání přání Svazu Čechů-židů nesla datum 28. května). Očekávaným podkladem mělo být vysvětlení základních principů národnostního statutu. Přestože Svaz Čechů-židů žádnou informaci z předsednictva neobdržel, přistoupil ke zpracování vlastních podnětů. Svou iniciativu zdůvodnil tím, že jeho vyjádření nesnese žádný odklad. Z referentské poznámky na průvodní informaci o československých Židech přitom vyplývá, že memorandum k připravovanému návrhu národnostního statutu bylo odevzdáno předsednictvu Ministerské rady prostřednictvím deputace Svazu Čechů-židů dne 6. května 1938. Materiál byl současně postoupen Vladimíru Ondrejčkovi, tajemníku předsedy vlády Milana Hodži, a také Františku Brüxovi, odborovému přednostovi předsednictva Ministerské rady. Do jaké míry byla tomuto podání věnována pozornost ze strany předsednictva a zda se v ovzduší bezprostředního ohrožení republiky memorandem zabýval některý z vládních úředníků, bohužel nelze z archivního materiálu zjistit. Dochovala se pouze referentská poznámka „a. a.“ s datem 18. 9. 1938 na první stránce spisu. Podepsána byla pravděpodobně Františkem Brüxem. ${ }^{18}$

$\mathrm{V}$ předložené studii se pokusíme analyzovat text českožidovského memoranda v kontextu tradice českožidovského myšlení, jeho loajality k českému národu a současně i rivalitního vztahu Čechů-židů k sionistické ideologii (ten se objevil již v devadesátých letech 19. století, tedy v okamžiku průniku sionismu do českých zemí). ${ }^{19}$ Našemu rozboru jsme předřadili základní informace o sociodemografických a společensko-politických východiscích židovského obyvatelstva v Československé republice a o dějinách zastř̌šující českožidovské organizace v Československé republice - Svazu Čechů-židů v Republice československé - v letech 1919-1939.

\section{Sociodemografická a společensko-politická východiska židovského obyvatelstva v Československé republice}

Po vzniku Československa žilo v českých zemích podle sčítání lidu v roce 1921 více než 10 mil. obyvatel národnosti „československé“ a 36 tisíc obyvatel národnosti židovské, kteří tvořili $0,36 \%$ obyvatel českých zemí. V roce 1930 se počet většinového obyvatelstva mírně zvýšil na 10,6 mil. a Židů na 37 tisíc, tj. na 0,37\%. Židovská národnostní menšina

\footnotetext{
16 Tamtéž, s. 118-119.

17 Tamtéž, s. 287.

18 Národní archiv Praha, fond Prezidium ministerské rady (dále jen NA, fond PMR), kart. 3217 - Memorandum. Text memoranda čítá 22 stran. Na průvodní čtyřstránkové informaci o Židech v Československu je razítko s datem 17. května 1938. Razítko podatelny prezídia při založení materiálu je z 20. září 1938.

19 Podrobně viz SOUKUPOVÁ, B. Česká společnost před sto lety. Identita, stereotyp, mýtus. Praha: Sofis, 2000, s. 160-162.
} 
tak byla početně nevýznamná. ${ }^{20} \mathrm{~V}$ Čechách žilo při prvním republikovém sčítání 11251 národních Židů, na Moravě 15335 a ve Slezsku 3 681. Při druhém sčítání byl zjišt'ován souhrnný počet pro Moravu a Slezsko (21 396), v Čechách se počet zvýšil jen nepatrně na 15 697. Vyšší byly součty židovského obyvatelstva podle víry: v roce 1921 v Čechách 79 777, na Moravě 37 989, ve Slezsku 7 317; v roce 1930 v Čechách zaznamenáváme však pokles na 76301 osob, na Moravě a ve Slezsku pak na 41250 osob. Židé podle víry tvořili při prvním republikovém sčítání asi $1,3 \%$ obyvatelstva. Vzhledem k možnosti přihlásit se v obou sčítáních k židovské národnosti, což bylo, jak uvádějí mnozí autoři, ${ }^{21}$ v meziválečné Evropě unikátní, poklesl počet jak židů hlásících se k německé, tak židů hlásících se k české národnosti. ${ }^{22}$ Podíváme-li se na sektorovou skladbu národnostních menšin v Čechách a na Moravě v roce 1921, zjišt’ujeme, že většina Židů náležela do sféry obchodu, peněžnictví, dopravy (5 434 a 7 734), prŕípadně průmyslu a živností (2 197 a 3370 ) a jen minimálně do sféry zemědělství. ${ }^{23}$ Také procentuální srovnání jasně dokládá, že židovské obyvatelstvo českých zemí (sčítané podle národnosti) v důsledku historického vývoje patřilo především do třetí sféry (obchod, peněžnictví, doprava). ${ }^{24}$

Náboženskou krajinu židovského obyvatelstva v českých zemích po první světové válce provázel, stejně jako náboženskou krajinu většinového obyvatelstva, úpadek. Povinná výuka náboženství byla zrušena a komunita byla vystavena asimilaci. Jak představitelé asimilantského českožidovského, tak konkurenčního sionistického hnutí (od roku 1920 s československým centrem v Moravské Ostravě ${ }^{25}$ ), tedy obě nejvýznamnější reprezentace židovského obyvatelstva v českých zemích, se shodovaly na tom, že se židovské náboženské obce mají demokratizovat, laicizovat a sdružit do celorepublikového svazu. Rozpory mezi asimilanty, sionisty a menšinovou skupinou ortodoxních Židů ovšem založení této organizace zabránily. ${ }^{26}$ Důležitou změnou, k níž došlo po vzniku Československa, bylo zastoupení českožidovských asimilantů v Židovské náboženské obci v Praze. Jejím předsedou se stal v roce 1921 August Stein.

Z historické literatury je známo, že emancipace rakouských Židů (a tedy i sociální vzestup) byla spojena s přijetím němčiny jako komunikačního jazyka, přesto se v českých zemích již ve čtyřicátých letech předminulého století některé židovské osobnosti hlásily $\mathrm{k}$ češtině. ${ }^{27} \mathrm{~V}$ šedesátých letech se židovské obyvatelstvo ztotožnilo s vládou německých liberálů; některé veřejně činné osobnosti však přešly na stanovisko německého nacionalismu.

20 MACHAČOVÁ, J. - MATĚJČEK, J. Sociální pozice národnostních menšin v českých zemích 1918-1938. Opava: Slezský ústav Slezského zemského muzea, 1999, s. 110-111. Autorská dvojice historických sociologů vychází z práce německého badatele Alfreda Bohmanna, viz BOHMANN, A. Das Sudetendeutschtum in Zahlen. Handbuch über den Bestand und die Entwicklung der sudetendeutschen Volksgruppe in den Jahren von 1910 bis 1950. Die kulturellen, soziologischen und wirtschaftlichen Verhältnisse im Spiegel der Statistik. München: Sudetendeutschen Rat, 1959, s. 47.

21 Např. ČAPKOVÁ, K. Uznání židovské národnosti v Československu 1918-1938. Český časopis historický, 2004 , roč. 102, č. 1, s. 77-103.

22 MACHAČOVÁ - MATĚJČEK, c. d., s. 116.

23 Tamtéž, s. 133.

24 V roce 1921 šlo o 50,7\% podíl, v roce 1930 se podíl snížil na 40,5\%. Viz MACHAČOVÁ - MATĚJČEK, c. d., s. 135.

25 Viz PĚKNÝ, c. d., s. 135.

26 Tamtéž, s. 339-340.

27 Souhrnně Tamtéž, s. 488-489, 498-506. 
Vlastní českožidovské hnutí se institucionalizovalo v sedmdesátých letech 19. století. ${ }^{28}$ Jeho základním kamenem bylo dobové chápání národa, jehož základními znaky byly jazyk, v širším časovém pojetí společně sdílený prostor a osudy (dějiny) a společná psychika. Čeští židé se označovali za Čechy židovského vyznání; vlastní asimilaci pak chápali jako sloučení a spojení, nikoliv jako ztrátu židovské identity. ${ }^{29}$ Již před rokem 1848 však bylo mnoho Židů žijících v Čechách bilingvních. Českou národně politickou orientaci si vybírali především méně majetní venkované žijící v českém vnitrozemí. ${ }^{30}$ Také převážně bilingvní pražští židé se již od přelomu 19. a 20. století hlásili rovnoměrně k češství i k němectví. ${ }^{31}$ Jejich školské vzdělání však zůstávalo zpravidla německé. ${ }^{32}$ Jak konstatovala i Michaela Peroutková, ani narození do německy mluvící židovské rodiny však neznamenalo, že by se její členové automaticky identifikovali s Němci. ${ }^{33}$

\section{Svaz Čechů-židů v Československé republice: vrcholná organizace českožidovského hnutí}

Tradice českožidovského spolkového života sahala do roku 1876. V odborné literatuře byla dějinám českožidovského spolkového hnutí opakovaně věnována pozornost. ${ }^{34}$ Po vzniku Československé republiky se objevily nové spolky, které navázaly na rakouské organizace, nebo došlo k transformaci již „tradičních“ korporací. Současně vznikla z iniciativy židovských náboženských obcí řada podpůrných, vzdělávacích a jiných jednot, které svou činností zareagovaly na oslabování ortodoxního Židovstva, liberalizační trendy v nové republice i na nové společensko-politické události bezprostředně se týkající židovského obyvatelstva. ${ }^{35}$ Nicméně velký rozmach zaznamenalo sionistické hnutí a jeho spolky po roce $1918 .{ }^{36}$ Pro účely našeho př́spěvku jsme se rozhodli představit pouze

28 Tamtéž, s. 506-508.

29 SOUKUPOVÁ, Česká společnost před sto lety, s. 127-129. K pojetí asimilace též PĚKNÝ, c. d., s. 508.

30 BIHL, W. Die Juden. In: WANDRUSZKA, A. - URBANITSCH, P. (eds.). Die Habsburgermonarchie 1848-1918. Die Völker des Reiches. Band III/2. Wien, 1980, s. 880-948.

31 HAVRÁNEK, J. Sociální struktura pražských Němců a Čechů, křest'anů a židů ve světle statistik z let 1890-1930. Český časopis historický, 1995, roč. 93, č. 3, s. 470-479.

32 COHEN, G. B. Němci v Praze 1861-1914. Praha: Karolinum, 2000, s. 171.

33 PEROUTKOVÁ, M. Židovské identity v Československu před 2. světovou válkou a po ní. Praha: Libri, 2016, s. 19-20.

34 Srov. např. KREJČOVÁ, H. Českožidovská asimilace. In: RYBÁR, C. Židovská Praha. Glosy k dějinám a kultuře. Průvodce památkami. Praha: TV Spektrum ve spolupráci s nakladatelstvím Akropolis, 1991, s. 108-156; COHEN, c. d., s. 170-172 (tento autor připomněl, že v devadesátých letech 19. století byly v českožidovském hnutí organizovány jen asi dvě až tři procenta pražského židovského obyvatelstva); PĚKNÝ, c. d., s. 508-509; SOUKUPOVÁ, B. Čeští Židé: deziluze jako impuls k vyprofilování sebevědomého českého židovství. In: SOUKUPOVÁ, B. - SALNER, P. Modernizace, identita, stereotyp, konflikt. Společnost po hilsneriádě. Bratislava: Zing print, 2004, s. 31-32; SOUKUPOVÁ, B. Spolek českých akademiků-židů, „Kapper“ a SAŽ v zápasech proti antisemitismu. In: JELÍNEK, T. - SOUKUPOVÁ, B. (eds.). Bílá mista ve výzkumu holocaustu. Praha: Spolek akademiků Židů, 2014: 297-319; ČAPKOVÁ, K. Češi, Němci, Židé? Národní identita Židů v Čechách 1918 až 1938. Praha - Litomyšl: Paseka, 2005, s. 94-99; KIEVAL, H. J. Formování českého židovstva. Praha - Litomyšl: Paseka, 2011, s. 45-47, 61-63.

35 Srov. např. KRUŽÍKOVÁ, J. Židovské náboženské obce a ortodoxní Židé v Československé republice ve dvacátých letech 20. století. In: SOUKUPOVÁ, B. - ZAHRADNÍKOVÁ, M. (eds.). Židovská menšina v Československu ve třicátých letech. Praha: Židovské muzeum v Praze, 2003, s. 98-105.

36 Legislativní rámec spolkového života Židů a veřejné působení židovských spolků v českých zemích v letech 1918-1948 podrobně zpracovali KŘESŤAN, J. - BLODIGOVÁ, A. - BUBENÍK, J. Židovské spolky v českých zemích v letech 1918-1948. Praha: Sefer a Institut Terezínské iniciativy, 2001. 
Svaz Čechů-židů v Republice československé jako autora memoranda. Dodejme, že tento dokument, který vznikl paralelně s připomínkami Židovské národní rady, vrcholného sionistického orgánu, činnost konkurenčního hnutí nezmínil.

Svaz Čechů-židů vznikl 12. října 1919 spojením dříve rivalitní Politické jednoty českožidovské a Svazu českých pokrokových židů. ${ }^{37}$ Současně se sloučila jejich periodika „Rozhled“ a „Rozvoj“, která začala vycházet pod názvem „Rozvoj“.38 V historické a etnologické literatuře bylo opakovaně konstatováno, že se tato organizace stala nejvýznamnější českožidovskou organizací, koordinátorkou a reprezentantkou života českých a slovenských židů, ${ }^{39}$ odmítající v zásadních otázkách spolupráci se sionistickým hnutím. ${ }^{40}$ Po vzniku Československé republiky odhadovala českožidovská reprezentace počet př́islušníků svého hnutí na 3000 osob, ale Svaz Čechů-židů měl oficiálně v roce 1920 pouze 853 řádných členů, ${ }^{41}$ v roce 1935 v Praze jen 674 členů, z toho 141 žen. Slabší pozice měl na Moravě (v Moravské Ostravě 59 členů, v Brně 22, v Jihlavě 12, v Olomouci a Prostějově po devíti), nepatrné pak na Slovensku. ${ }^{42}$

Do nejkritičtějších třicátých let vešel Svaz Čechů-židů po generační výměně: vedle nového předsedy Otty Strosse se i do dalších funkcí dostali představitelé mladší střední generace. ${ }^{43}$ Historička Helena Krejčová vyjmenovala řadu př́kladů loajality této organizace $\mathrm{k}$ československému státu. V závěru podtrhla, že v roce 1938 Češi-židé vybrali 80 mil. Kč ve sbírce určené na obranu republiky. ${ }^{44}$ Dodejme, že právník a filozof českožidovského hnutí Jindřich Kohn, hlavní autorita Svazu Čechů-židů, byl dokonce autorem myšlenky bojkotu samostatné židovské protihitlerovské politiky. ${ }^{45}$ Vedle sbírky na obranu státu však Svaz v roce 1938 podporoval i další československé akce: dubnové slavnosti míru Československého červeného kříže, květnovou a zářijovou mobilizaci, květnové volby, sokolský slet. ${ }^{46}$ Bezesporu nejvýznamnější akcí spolku se však stala dvoutisícová manifestace na téma Rasové zákony a demokracie, která se konala 9. října 1935 v pražské Plodinové burze. ${ }^{47}$

37 KŘESŤAN, J. Židovské spolky a česká společnost. In: KŘESŤAN, J. - BLODIGOVÁ, A. - BUBENÍK, J. Židovské spolky v českých zemích v letech 1918-1948. Praha: Sefer a Institut Terezinské iniciativy, 2001, s. 27; PĚKNÝ, c. d., 518; SOUKUPOVÁ, B. Velké a malé českožidovské přiběhy z doby intenzivní naděje. Bratislava: Zing print, 2005, s. 140 (autorka Blanka Soukupová využila ve své práci mj. poznatky z výzkumu v Archivu města Prahy, fond Policejní ředitelství 995 (XXI/149), 1919-1951).

$38 \quad \mathrm{~K}$ tomu srov. např. KIEVAL, c. d., s. 275.

39 KREJČOVÁ, c. d., s. 140; ČAPKOVÁ, Čěsi, Němci, Židé, s. 134.

40 SOUKUPOVÁ, B. Identita Čechů židů v nové evropské realitě. In: POJAR, M. - SOUKUPOVÁ, B. - ZAHRADNÍKOVÁ, M. (eds.). Židovská menšina v Československu ve třicátých letech. Praha: Židovské muzeum v Praze, 2004, s. 47.

41 SOUKUPOVÁ, B. Velké a malé českožidovské přiběhy, s. 139-140.

42 SOUKUPOVÁ, Identita Čechů židi̊, s. 44; SOUKUPOVÁ, Velké a malé českožidovské přiběhy, s. 181.

43 SOUKUPOVÁ, Identita Čechů židi̊, s. 43-44; SOUKUPOVÁ, Velké a malé českožidovské přiběhy, s. 180-181; dále srov. KŘESŤAN, c. d., s. 39.

44 KREJČOVÁ, $c$. d., s. 141.

45 SOUKUPOVÁ, Spolek českých akademiků-židů, s. 318; KřESŤAN, c. d., s. 41.

46 SOUKUPOVÁ, Identita Čechů židi̊, s. 45; SOUKUPOVÁ, Velké a malé českožidovské přiběhy, s. 182.

47 KřESŤAN, c. d., s. 42. 


\section{Průvodní informace o Židech v Československu připojená k memorandu optikou českožidovského hnutí}

K vlastnímu memorandu připojil Svaz Čechů-židů výsledky ze sčítání lidu v Československu v roce 1930. Z podání přitom vyplývá, že většina z 356830 Židů podle víry se přihlásila k židovské (186 642 osob) nebo československé (87 489 osob) národnosti. Následovaly národnost německá (45 732 osob), mad'arská (16 807 osob), ruská a ukrajinská (1086 osob), polská (818 osob), rumunská (171 osob), ,jihoslovanská“ (80 osob) a nespecifikované další. Současně i v této situaci ohrožení státu reprezentace zastřešující českožidovské instituce vyzdvihla zásadní názorové neshody mezi asimilanty a ortodoxními Židy na jedné a sionisty na druhé straně. Ideologickou nesmiřitelnost těchto hlavních tří politickoideologických směrů přitom nadřadila nad společnou židovskou víru. V souladu se skutečností pak konstatovala, že pouze českožidovští asimilanti si vytvořili své vlastní organizace (tzv. němečtí Židé se skutečně sdružovali pouze v rámci německých spolků). Následně je uveden stručný nástin českožidovského korporativního hnutí i českožidovského tisku a prezentace hlavních cílů (splynutí s českým národem) i zásluh českožidovského hnutí (zrušení židovských náboženských škol s německou vyučovací řečí, počeštění obchodních a živnostenských komor v Praze, Českých Budějovicích i Plzni), dále angažmá českých Židů v legiích, perzekuce hnutí během první světové války, obhajoba československých státních zájmů po vzniku republiky, tj. příprava plebiscitu na Těšínsku, Spiši a Oravě, a zejména popis českožidovského hnutí, které usilovalo o získání Židů pro myšlenku česko(slovensko)židovské asimilace na Moravě, ve Slezsku a na Podkarpatské Rusi.

Paralelně s výše uvedeným se ve zprávě realisticky konstatuje, že asimilační hnutí na Slovensku je teprve ve fázi zrodu. Pokud podrobíme českožidovskou argumentaci analýze, zjišt'ujeme, že byla v souladu s dosavadním směřováním českožidovského hnutí. Rušení židovských náboženských škol s němčinou jako vyučovacím jazykem bylo jedním z cílů českožidovského programu již od devadesátých let 19. století, kdy hnutí vyhlásilo heslo „Česká škola, český chrám, český krb“. Německo/židovské školy odsuzovalo českožidovské hnutí jako instituce oddělující židovské děti od dětí nežidovských, pedagogicky zastaralé, jako instituce vedoucí k „národní obojakosti“.48 Podle amerického profesora Hillela J. Kievala klesl v letech 1894 až 1907 počet německo/židovských škol v Čechách ze 113 na 90. V roce 1906 Národní jednota českožidovská uvedla, že v letech 1893 až 1906 zaniklo 52 německožidovských škol. ${ }^{49}$ Po převratu zůstala jedna škola v Čechách (v Teplicích-Šanově), 25 na Moravě a 100 na Slovensku. ${ }^{50}$ Zatímco v prrípadě uzavření škol položil Kieval otázku, zda šlo skutečně o zásluhu českožidovského hnutí, ${ }^{51}$ podíl česky orientovaných Židů na vítězství české strany v obchodních a živnostenských komorách je nezpochybnitelný. Často je přitom uváděno, že se prvním českým prezidentem obchodní

\footnotetext{
48 Naše dítky do českých škol! Českožidovské listy, 1895, roč. 1, č. 24. Ve stejném duchu se k tomuto problému vyjadřovaly i přední osobnosti českožidovského hnutí: poslanec Ferdinand Schwarz, Maxmilian Reiner. KIEVAL, $c$. d., s. 83, 86 .

50 SOUKUPOVÁ, B. Několik poznámek k počátkům sionistického modelu výchovy za první republiky. In: KASPER, T. - KASPEROVÁ, D. (eds.). Češi, Němci, Židé v národnostním Československu. Pohledy na školství a vědu. Liberec: Technická univerzita v Liberci, 2006, s. 56.

51 KIEVAL, c. d., s. 86, 88.
} 
komory v Praze stal v roce 1884 Bohumil Bondy, velkoobchodník a továrník. ${ }^{52}$ Obdobně se v odborné literatuře konstatuje i to, že během první světové války zaujali někteří čeští Židé protirakouský postoj a dokonce vstoupili jako dobrovolníci do legií; jen v Rusku jich mělo bojovat více než $600 .{ }^{53} \mathrm{~S}$ odvoláním na práci historičky Heleny Krejčové Tomáš Pěkný ve své dosud nepřekonané kompilační syntéze uvedl jako nezpochybnitelnou skutečnost i agitaci českožidovského hnutí při plebiscitech. ${ }^{54}$ Naopak s velkými problémy se potýkala činnost českožidovského ústředí mimo Čechy. Po převratu působily na Moravě pouze čtyři českožidovské organizace: od roku 1911 v Moravské (někdejší Slezské) Ostravě o asi 100 členech, v Brně (od roku 1913 se 40 členy), v Olomouci a v Jihlavě od roku 1919 o 104 až 300 členech. ${ }^{55}$

Jako „tradiční“ zůstala i českožidovská charakteristika sionistického hnutí. V průvodní informaci k memorandu je sionismus charakterizován nikoliv jako nové národní hnutí, ale jako ideologie, jíž vytvořil antijudaismus, ${ }^{56}$ a po převratu se stala útočištěm pro Židy německé orientace, kteří se nechtěli přihlásit k československé (německé) národnosti. Informace velmi účelově vyzdvihla i údajnou sionistickou neloajalitu k republice (vlastí sionistů je Palestina); nově se objevila i kritika, že hnutí provádí menšinovou politiku a je v koalici s českými sociálními demokraty, ${ }^{57}$ přestože se současně tvrdilo, že sionisté jsou loajálními Čechoslováky. I nadále zůstal jádrem českožidovského odmítnutí sionismu jeho koncept národa (národními atributy měly být jazyk, společné území, kultura). ${ }^{58}$ Obdobně účelově podtrhla informace také menšinové zastoupení sionismu mezi Židy v Čechách i na Moravě a ve Slezsku; a naopak: ze stejného důvodu se vyhnula uvedení statistických dat na Slovensku a Podkarpatské Rusi. ${ }^{59}$

V závěru se věnovala průvodní informace židovské ortodoxii. Přestože se před první světovou válkou někteří představitelé českožidovského hnutí, zejména Viktor Vohryzek, ${ }^{60}$ vymezovali vůči ortodoxii negativně, jsou v textu charakterizováni ortodoxní Židé jako „oddaní př́́slušníci československého národa“, jejichž děti navštěvují české nebo slovenské školy. Informace upozornila i na tu skutečnost, že tento směr reprezentují pouze kanceláře v Bratislavě a Užhorodě a že celostátní svaz se sídlem v Brně teprve vzniká. Vlastní příčiny pozitivního hodnocení ortodoxie lze ovšem najít už v dalších řádkách; českožidovské hnutí si bylo dobře vědomo té skutečnosti, že mezi sionismem a ortodoxií

52 KOŘALKA, J. Češi v habsburské řiši a v Evropě 1815-1914. Praha: Argo, 1996, s. 162. K tomu srov. i SOUKUPOVÁ, Češti Židé, s. 33.

53 PĚKNÝ, c. d., 514.

54 Tamtéž, s. 515.

55 SOUKUPOVÁ, Velké a malé českožidovské př́běhy, s. 141.

56 Přední představitelé českožidovského hnutí v devadesátých letech 19. století ovšem také dokazovali, že sionismus antisemitismus i podporuje. Srov. SOUKUPOVÁ, Česká společnost před sto lety, s. 162.

57 Židovská strana československá (zal. 1919) utvořila tuto koalici ve volbách v roce 1935. Viz PĚKNÝ, c. d., s. 526.

58 V devadesátých letech 19. století zdůrazňovalo českožidovské hnutí navíc i společně prožité dějiny a podobnost mentality. Viz SOUKUPOVÁ, Velké a malé českožidovské prriběhy, s. 161.

59 Na Slovensku se v roce 1921 přihlásilo k židovské národnosti 54,28\%, na Podkarpatské Rusi dokonce 86,31 \% československých Židů. V rámci celé republiky tak židovskou národnost uvedlo 51 \% Židů podle víry. Viz PĚKNÝ, c. d., s. 527.

60 KIEVAL, $c$. d., s. 138-140. Podle Blanky Soukupové ke kritikům ortodoxie patřili také např. Otakar Guth či Viktor Teytz. Viz SOUKUPOVÁ, Čeští Židé, c. d., s. 59-60. 
panují rozpory. Posílení ortodoxie na Slovensku a na Podkarpatské Rusi by tak znamenalo zeslabení sionistického hnutí.

Příčinu rozporů mezi národními a ortodoxními Židy viděla průvodní informace v tom, že sionisté používali hebrejštinu jako národní jazyk, zatímco pro ortodoxní Židy jde o jazyk posvátný, a proto se jejich komunikační řečí stalo „nářečí“ jidiš. Druhou př́ičinou rozkolu měl být rozdílný vztah k judaismu; pro ortodoxní Židy pojítku všech Židů. Skutečnost byla pochopitelně ještě složitější. Sionisté se od ortodoxních Židů lišili také v názorech na demokratizaci náboženských obcí a konečně i na ženskou emancipaci. Sionistickým ideálem se stala politicky se angažující žena. ${ }^{61}$ Moderní postavení ženy ve společnosti tak bylo samozřejmě v rozporu s ženiným úkolem vyvěrajícím z tradičního judaismu.

\section{Memorandum, jeho struktura a obsah v kontextu programových zásad českožidovského hnutí}

Vlastní text memoranda byl strukturován do tř́i částí. První část shrnula názory a připomínky českožidovského hnutí, které Svaz Čechů-židů předložil jako podklad ke zpracování návrhu národnostního statutu, jenž měl řešit národnostní otázky podle zásady proporcionality a samosprávy. Druhá část obsahovala několik poznámek a odkazů k rozvrstvení Židů v Československu. Třetí přinesla podrobnější výklad programového zaměření Svazu Čechů-židů.

Za klíčový problém v otázce proporcionality pokládalo memorandum zjišt’ování národnosti. Svaz Čechů-židů samozřejmě odmítl pojetí německého nacionálního socialismu, podle něhož byl národ „společenstvím krevním“. Současně však nepřitakal zcela ani tezi biologa a filozofa Emanuela Rádla, podle něhož byl výběr národnosti aktem volby. Ostatně: českožidovskému hnutí musela být známa kritika Rádlovy knihy Válka Čechů s Němci (1928), kterou Ferdinand Peroutka, její autor, otiskl v týdeníku Přítomnost. Jednou z kritizovaných tezí se stala právě Rádlova představa o svobodné volbě národnosti. ${ }^{62}$ V duchu svého programu pak českožidovské memorandum objasnilo svůj názor na určování „národní“ příslušnosti: přes respekt k individuálnímu sebeurčení hrály podle něj důležitou roli také tzv. objektivní znaky národnosti (mateřský jazyk, národnostní charakter školního vzdělání). Kombinaci těchto dvou hledisek (volba jedince a objektivní znaky) zdůvodnilo českožidovské hnutí jak postojem československé státní správy uplatněném při sčítání lidu, tak objektivně existujícím politickým tlakem, jenž nutil lidi z existenčních důvodů nepřihlásit se ke své národnosti (memorandum uvedlo př́klad Čechů na kandidátce Henleinovy Sudetoněmecké strany). Hlavním zájmem Svazu Čechů-židů se však stalo uplatnění objektivních znaků v případě židovské menšiny v Čechách, na Moravě a ve Slezsku (tj. zemi české a moravskoslezské či v historických zemích Koruny české). Ta podle názoru českožidovského hnutí nenaplňovala tyto národní atributy: kultura, jazyk (tzv. novohebrejština, tedy „ivrit“), školství, společné teritorium. Ještě na počátku záŕí

61 SOUKUPOVÁ, Velké a malé českožidovské príběhy, s. 196-197, 200-201.

62 Pro Peroutku byla národnost ,něco daného a objektivního ... Národ je asi společenství jistého průměru osudu, místa, tradice, zvyků, kultury, setrvačnosti, věrnosti k praporu, zájmů, vůle, úmyslů; národ je v tom, Že lidé volky nevolky musí sdílet osud svého národa..."Viz SOUKUPOVÁ, B. Rakousko-Uhersko, Němci a Německo v Peroutkově Př́itomnosti I. (do př́íchodu nacistů k moci v Německu roku 1933). Československá demokracie a etnické stereotypy. Lidé města, 1999, 1, s. 88. 
1938 Josef Bondy v českožidovském Rozvoji napsal: „Přihlášení se k židovské národnosti bylo pro velikou většinu východiskem z nouze, aktem bezradnosti, svědectvím národnostního přerodu $\mathrm{z}$ uměle udržovaného němectví k přirozené asimilaci české a slovenské.“63

Objektivní národní znaky memorandum přiznávalo pouze Židům žijícím na východě Československa (zejména na Podkarpatské Rusi), kteří v běžném denním kontaktu používali jidiš (v mínění českožidovského hnutí židovský žargon, psaný německy ,jüdisch“) a byli nositeli židovské kultury. Současně ovšem českožidovská reprezentace dodávala, že se jedná o skupinu ortodoxních Židů, jež ze své podstaty neuplatňuje princip politické národnosti. Důležité bylo také to, že memorandum neupozornilo na jinakost sionistického pojetí národa oproti pojetí asimilantskému (podle národních Židů měl mít každý národ svou duši, jazyk a stát), ${ }^{64}$ na propracovaný sionistický program politizace židovských náboženských svátků, které se měly stát páteří sionistické (židovské národní) kultury, a konečně i na důkladně promyšlený program jazykový: každý sionista si měl osvojit hebrejštinu v židovských národních školách nebo v jazykových kurzech (např. spolku „Ivriah“). ${ }^{65}$ Pravdivá nebyla ani informace o neexistenci židovského školství v českých zemích (např. pražská jednotřídka začala vyučovat v roce 1920); již od konce roku 1909 působila v Čechách Židovská Matice školská, jež pražskou pětitř́inní obecnou školu a opatrovnu s českou vyučovací řečí vydržovala. ${ }^{66}$ Volba státního jazyka jako jazyka výuky byla výsledkem loajality sionistického hnutí vůči novému státu i výsledkem pragmatické pedagogické úvahy: „národní“ jazyk se židovské děti musely teprve ve škole naučit, protože ze svých rodin si prrinášely zpravidla nerovnoměrnou znalost němčiny a češtiny. Naopak v Mukačevu mohlo být otevřeno hebrejské gymnázium (první československé hebrejské gymnázium tu vzniklo už pro školní rok 1918/1919).

V př́ípadě určování objektivních národních znaků uplatňovalo českožidovské hnutí zásady svého dosavadního programu, který byl konkurenčním vůči programu sionistickému. V nahlížení na otázku tzv. proporcionality oscilovalo českožidovské hnutí mezi ideálním demokratickým postojem (každý se má uplatnit podle svých schopností, bez ohledu na národnost, náboženské vyznání apod. ${ }^{67}$ ) a mezi loajalitou k Československé republice, jež pod silným politickým tlakem chtěla zavést dnešní terminologií pozitivní diskriminaci menšin. Českožidovské hnutí ji bylo však ochotno respektovat pouze v oblasti veřejných

63 Národnostní statut a židovská otázka. Rozvoj, 1938, 45, 35-36, s.1.

64 Srov. SOUKUPOVÁ, Velké a malé českožidovské př́běhy, s. 195-196, 199-201.

65 Hebrejština měla stmelit Židy v diaspoře, dát jim vědomí židovské tradice, posílit židovskou identitu a konečně překlenout vzdálenost mezi diasporou a Erec Jisrael. Viz SOUKUPOVÁ, Velké a malé českožidovské príběhy, s. 203-204.

66 Podle Blanky Soukupové v roce 1922 vydržovali sionisté již tři soukromé školy: v Praze, v Brně, v Moravské Ostravě a šest škol na Podkarpatské Rusi s hebrejským vyučovacím jazykem. První maturita na židovském gymnáziu v Brně proběhla v roce 1928. Viz SOUKUPOVÁ, Několik poznámek k počátkům, s. 59-60. Dana Kasperová pak uvedla, že v Brně vzniklo vedle obecné školy české židovské spolkové reálné gymnázium. Viz KASPEROVÁ, D. Židé a školství v prvorepublikovém Československu. In: KASPER, T. - KASPEROVÁ, D. (eds.). Čě̌i, Němci, Židé v národnostním Československu. Pohledy na školství $a$ vědu. Liberec: Technická univerzita v Liberci, 2006, s. 51.

67 Tento postoj lze zaznamenat i v reakci na kontroverzní úvodník Ferdinanda Peroutky, otištěný v Přítomnosti na počátku roku 1938. Peroutka v něm hájil stanovisko, že nízká míra antisemitismu v české společnosti byla výsledkem „určitého rozumného procenta“ českých Židů v českém veřejném a hospodářském životě. Židovští čtenáři Přítomnosti tyto ,počty“ striktně odmítli. Viz SOUKUPOVÁ, B. Peroutkova Přítomnost, židé a Židé (1924-1939). Lidé města, 2000, 4, 36-79. 
služeb a institucí, nikoliv ve sféře podnikání, ve vědě a v umění, kde vedle předpokladu kvalifikace Svaz Čechů-židů podtrhoval i podmínku loajálnosti podnikatelského subjektu ke státu, jejíž součástí měla být i činnost vedoucí k národnostnímu (,rasovému“) smíru. Zavedení zásady proporcionality navíc podle českožidovského hnutí nikdy Židé nežádali, a tak by se mohla uplatnit maximálně ve vztahu k těm, kteří se hlásí k židovské národnosti. Uplatnění plošné proporcionality ve vztahu k Židům by nadto podle memoranda zabránilo přirozené asimilaci židovského obyvatelstva k československému národu. Pokud by pak byla proporcionalita spojena s bezvýhradnou volbou národnosti, vedlo by to naopak Židy ke konjunkturálnímu přihlašování se ke státnímu národu, které by poškodilo morální kredit českožidovského hnutí.

Zvláštní pozornost pak věnovalo memorandum zavedení proporcionality ve sféře školství. Stejně jako za Rakousko-Uherska, i v nové republice českožidovské hnutí brojilo proti židovskému menšinovému školství (i v tomto př́padě bylo ochotno princip proporcionality akceptovat pouze pro př́íslušníky židovské národnosti68). Nově mohlo ovšem argumentovat tím, že se v českých zemích vyučovalo ve školách zpravidla česky a naopak na Podkarpatské Rusi nebyl vyučovací jazyk totožný s jazykem denní komunikace (jidiš). Tamější ortodoxní komunita navíc o židovské školství údajně nestála. Vzhledem k údajnému znesvěcení hebrejštiny jako svatého jazyka hrozili tamější rabíni rodičům, jejichž děti židovské školy navštěvovaly, pekelnými tresty. ${ }^{69}$ Pro kulturně smíšené školy mluvila podle memoranda schopnost těchto škol sbližovat židovské žáky s nežidovskými, a zabraňovat tak antisemitismu, který údajně vycházel z pocitu cizosti. Také s tímto zdůvodněním bychom se setkali, jak jsme již zdůraznili, už v devadesátých letech 19. století.

Z logických příčin, především vzhledem k postavení židovské menšiny v pohraničí, nebylo českožidovské hnutí ani příznivcem národnostní samosprávy. Proto memorandum vyslovilo důvěru v to, že i v této oblasti bude státem hájeno občanské právo každého jednotlivce. Zcela oprávněně upozorňoval v těchto souvislostech spis na rozsáhlou protižidovskou kampaň Henleinovy strany a jejího tisku. ${ }^{70}$ Obdobný charakter mělo podle něj i tzv. l'ud'ácké hnutí na Slovensku. Narůstající antisemitismus by pak, jak spis upozorňoval, mohl vyvolat rozsáhlou migrační vlnu tamějšího Židovstva do vnitrozemí státu, jež by mohla vést k politickému i hospodářskému neklidu. Dodejme, že v tomto př́ípadě memorandum pouze předpovědělo situaci, která nastala po mnichovské dohodě na konci záŕí $1938 .{ }^{71}$

Druhý oddíl memoranda, přes svůj název „Rozvrstvení Židů v Československu“, neobsahoval ani charakteristiku Židů podle národnosti či ideologicko-politické orientace, ani

68 Na tomto místě se připomíná, že příslušníci českožidovského hnutí by byli naopak při uplatnění principu proporcionality na všechny Židy odnárodňováni. I v tomto případě ovšem Svaz zdůrazňoval zájem státního národa neposílat děti svých členů do menšinových škol.

69 SOUKUPOVÁ, Několik poznámek k počátkům, s. 61.

70 V srpnu 1938 vydala Židovská náboženská společnost v Praze memorandum proti pronásledování židovského obyvatelstva v pohraničí henleinovským hnutím. Viz SOUKUPOVÁ, Velké a malé českožidovské př́běhy, s. 211. Podrobně viz též MÍŠKOVÁ, A. Židé v Sudetech. Od Schönerera ke genocidě. Roš chodeš, 1998 , roč. 60,3 , s. 8-9.

71 K uprchlickému problému souhrnně GEBHART, J. - KUKLÍK, J. Druhá republika 1938-1939. Svár demokracie a totality v politickém, společenském a kulturním životě. Praha - Litomyšl: Paseka, 2004, s. 171-172. Proces vyhánění Židů z Říšské župy Sudety narostl již v říjnu 1938. K takřka úplnému vyhnání Židů došlo pak po „křišstálové noci“ (tamtéž, s. 32-33). 
údaje o geografickém rozsídlení Židů. Text se omezil na konstatování, že členy Svazu Čechů-židů jsou Židé podle víry, české nebo slovenské národnosti a samotný spolek je státotvornou institucí. Existenci samostatného „Zväzu slovenských židov“ odůvodnilo memorandum důvody taktickými a organizačními. ${ }^{72}$ Dále text odkázal na tři přílohy, které Svaz připojil k memorandu: na materiál ze setkání jeho zástupců v květnu 1938 s novinárii, na brožuru Ervína Neumanna Práce, program a cíl Svazu Čechů-židů v ČSR (duben 1937), v níž Neumann prosazoval myšlenku spolupráce asimilovaných Židů v rámci Malé dohody, ${ }^{73}$ a na brožuru svého předsedy Otty Strosse Vývoj židovské otázky po světové válce (červen 1937).

Poslední část memoranda, nazvaná „Náš program“, byla věnována sebeprezentaci Svazu Čechů-židů. V úvodu spolek, po konstatování, že se většina jeho členů hlásí k judaismu, vyzdvihl potřebu „rabínského učiliště“. Nečeskoslovenští rabíni podle něj totiž nemohli vychovat své žáky k národní a státní loajalitě. Ani tato myšlenka nebyla nová: ideu učiliště, na němž by byl vychováván nový kádr československých rabínů, prosazovalo memorandum Svazu Čechů-židů, zaslané československé vládě, již v roce 1920. Českožidovský kolínský rabín Richard Feder ji podpořil na jaře 1924 před sjezdem českých židovských náboženských obcí. Již tehdy si českožidovské hnutí také stěžovalo na příliv rabínů z Haliče, Bukoviny a Vídně. ${ }^{74}$ Role státu byla chápána jako klíčová i v prrípadě dozoru nad židovskými náboženskými obcemi (s odvoláním na zákon č. 57/1890 ř. z.). I v tomto př́ípadě chtěl Svaz Čechů-židů oslabit pozice sionistického hnutí (vysoce účelová byla jeho stížnost na obec v Moravské Ostravě, baště sionistického hnutí, jež vydávala téměř třetinu svých finančních prostředků z náboženské daně ${ }^{75}$ na podporu sionistických korporací, palestinských fondů a tamější židovskou školu).

Rozširrení pozic českožidovského hnutí si memorandum slibovalo rovněž od demokratizace volebních řádů v obcích, sloučení sedmi obcí v jednu obec Velké Prahy (na základě rezoluce Národního shromáždění při příležitosti zákona č. 9/1937 Sb. z. a n.) a schválení ústavy Nejvyšší rady židovských náboženských obcí76 československou vládou. V ústavě byla totiž odmítnuta politická aktivita obcí (tento požadavek podpořilo i ortodoxní Židovstvo) a požadována znalost státního jazyka ze strany menšinových funkcionářu. ${ }^{77}$ Svaz Čechů-židů rovněž požadoval uplatnění jazykového zákona v obcích podle poměrného zastoupení všeho (nikoliv pouze židovského) obyvatelstva.

72 Pozice asimilantského hnutí na Slovensku byly ovšem velmi slabé. V roce 1935 měl Zväz v Bratislavě, v centru slovenskožidovských snah, jak zmiňuje Blanka Soukupová, pouze 18 přívrženců. SOUKUPOVÁ, Velké a malé českožidovské přiběhy, s. 181.

73 NEUMANN, E. Práce, program a cíl Svazu Čechů-židů v ČSR. Praha: [s.n.], 1937, s. 23.

74 SOUKUPOVÁ, Velké a malé českožidovské př́běhy, s. 147.

75 Tuto daň platili, jak zdůraznilo memorandum, i přívrženci českožidovského hnutí. Sionistické aktivity byly i v tomto př́ipadě programově označeny za protičeskoslovenské, sloužící k separaci židovské menšiny. V listopadu 1937 rozhodl Zemský úřad v Brně o zrušení stanov obce. Komentuje to autor pod šifrou „By.“- Stanovy ostravské náboženské obce zrušeny. Rozvoj, 1937, 44, 47, s. 1.

76 Tehdejší Nejvyšší rada židovských náboženských obcí podle Svazu Čechů-židů nevzešla z demokratických voleb, a proto by měly být dle memoranda diskutovány a řešeny problémy obcí v rámci ankety na ministerstvu školství a národní osvěty.

77 Podle memoranda ústavu podepsalo 26 obcí (blíže nespecifikovaných). Svaz Čechů-židů odmítl rovněž utvoření Svazu židovských náboženských obcí „,s německým úředním jazykem“. 
Dalším důležitým programovým úkolem Svazu Čechů-židů se stal boj s antisemitismem (v terminologii memoranda s antijudaismem). V souladu se svou tradicí označilo českožidovské hnutí tento zápas za účinný jen tehdy, pokud se podaří zvýšit kulturní a etickou úroveň národa. Českožidovské hnutí přitom upozornilo na předstupně současného rasového antisemitismu: antijudaismus, národní a hospodářský antisemitismus. Náboženský antisemitismus pokládalo za přežilý, národní antisemitismus měl již zdroj údajně pouze v „němčení“ starší židovské generace, hospodářský antisemitismus ztrácel své impulsy tzv. převrstvováním židovské mládeže. Současně však českožidovské hnutí upozorňovalo na to, že židovská neúplná sociální struktura vznikla v důsledku historického vývoje a že demokratický stát nemůže bránit volné soutěži talentů.

Za hlavní šiřitele dobového antisemitismu pokládalo memorandum školu (sic!), právě tak jako regionální a antisemitský tisk, nikoliv periodika ústředních politických stran. I tady měl zasáhnout podle memoranda stát, jenž měl vydat pokyny pro učitele zeměpisu a dějepisu, které by zakazovaly interpretovat hospodářskou a sociální zaostalost ve východních oblastech republiky a komunismus v sovětském Rusku jako židovské dílo. Antisemitismu v tisku měl stát předcházet preventivní cenzurou a důsledným trestním postihem zodpovědných osob. Memorandum upozorňovalo na to, že dosud cenzuře předchází rozdávání závadných tiskovin na ulicích, v kavárnách i před školami.

V závěru memoranda se Svaz Čechů-židů věnoval nejaktuálnějším úkolům českožidovského hnutí, které spatřoval ve zvýšení intenzity svého působení na Moravě, ve Slezsku, na Slovensku a na Podkarpatské Rusi. Současně bilancoval své úspěchy (plebiscit na Podkarpatské Rusi, zájem tamější židovské mládeže o české školy, vznik Zväzu slovenských židov v Bratislavě a spolku Rozvoj v Košicích). Za své institucionální spojence přitom Svaz Čechů-židů označil Československou národní radu se čtyřmi českožidovskými zástupci a Československé mírové souručenství.

Svaz Čechů-židů považoval také za svůj aktuální úkol usilovat o zabránění prvoplánové migrace Židovstva z regionů ohrožených antisemitismem do vnitrozemí. Řizená migrace měla být až druhým krokem, přičemž vystěhování do zahraničí pokládalo českožidovské hnutí za krajní řešení. Dodejme, že svůj nesouhlasný vztah k emigraci začalo českožidovské ústředí zmírňovat až v období tzv. druhé republiky. ${ }^{78}$ I nadále se českožidovské hnutí tedy prezentovalo jako již tradiční součást českého kulturně politického života, jako loajální složka československého státu, která posiluje postavení národa i státu. Od ostatních Čechoslováků se asimilovaní čeští Židé liší údajně pouze svou vírou, proto také mají volit kandidátní listiny „,̌eskoslovenských demokratických národních stran“. Odkazováno je např́klad na výsledky obecních voleb v Praze (1931, 1938), kde zvláštní židovská kandidátka (původně německožidovská) zásluhou hnutí propadla. „Asimilační hnutí není tedy snad jen prací pro židy, nýbrž především také pro posílení celého československého národa," zdůraznilo memorandum.

78 Na počátku roku 1939 byla emigrace již hodnocena jako možnost, která nemá být posuzována negativně. Srov. SOUKUPOVÁ, B. Reflexe Mnichova a českožidovské strategie v období tzv. druhé republiky. In: ZOUFALÁ, M. - HOLÝ, J. (eds.). Rozpad židovského života. 167 dni druhé republiky. Praha: Academia, 2016, s. 189. 


\section{Závěrem}

Jak jsme uvedli v úvodu př́spěvku, při studiu archivního materiálu předsednictva Ministerské rady jsme nenalezli doklady o tom, že by československé orgány připravující národnostní statut věnovaly připomínkám vrcholné českožidovské organizace nějakou pozornost. Dochoval se pouze záznam, podle něhož bylo ve druhé polovině záŕí 1938 memorandum odloženo ad acta. Položme si tedy otázku, jaký byl vztah většinové společnosti k českožidovskému hnutí, a rovněž, jaká byla pozice antisemitismu v první československé republice.

Desetiletí etablované českožidovské hnutí v Československé republice bylo ze strany vládních orgánů vysoce respektované. Sám prezident T. G. Masaryk usiloval o vyrovnaný poměr $\mathrm{k}$ sionistickému, asimilantskému i ortodoxnímu židovskému hnutí, přestože jeho sympatie byly na straně národněžidovského (sionistického) hnutí. ${ }^{79}$ Po odeznění počáteční poválečné vlny antisemitismu se českým Židům otevřely všechny politické strany, spolky a společenství. ${ }^{80}$ Tolerantní vztah k českožidovskému hnutí ze strany vládních institucí, prítomnost mnoha zastánců českožidovského hnutí ve vysokých funcích na všech úrovních, respekt k českožidovským osobnostem a konečně společenská nepatřičnost antisemitismu náležely k piliřům první republiky. Přesto se prvorepubliková česká společnost antisemitismu nikdy zcela nezbavila. Radikální tvrzení o neschopnosti Židů asimilovat k českému národu, tzn. uskutečnit hlavní cíl českožidovského hnutí, se pak stalo jedním z leitmotivů ve vyhroceně nacionalistických (fašistických) politických stranách. ${ }^{81}$

K charakteristice pozic antisemitismu v Československé první republice dlužno dodat, že po bouřlivých pogromových letech 1918-1920, v nichž vznikla celá řada antisemitských proudů a na ně navázaných periodik (Staroslovan - týdeník sdružených staroslovanských organizací, později Všeslovanské jednoty, Štít republiky československé a s ním spjaté Republikánské sdružení očisty a politického sjednocení v Praze, Slovanská strana sociální a její periodikum Naše snahy, Slovanská strana protižidovská a její tisk Štít národa), se antisemitismus dostal na okraj české politické scény. Vznik protofašistického (1922-1923) a fašistického hnutí (1926 zrod Národní obce fašistické, jejímž ústředním periodikem se stala Národní republika) podnítil demokratické politické síly i občanskou společnost k větší aktivitě. Výrazem tohoto úsilí byla i rekonstrukce vlády všenárodní koalice na podzim 1922. Také agrární strana, nejsilnější politická síla, odsunula antisemitismus mimo hlavní politický proud. Toto konstatování však samožrejmě neznamená, že by se antisemitismus ze stranického tisku vytratil, jelikož na stránkách agrárního, národnědemokratického a též živnostnicko-obchodnického tisku se objevovaly protižidovské stereotypy po celé období první republiky. Podobně nezmizely ani antisemitsky laděné přednášky, antisemitské tituly a výstavy (v roce 1925 vystavoval v Praze své antisemitské perokresby akademický malíŕ Karel Rélink). Vedle toho existoval i tzv. antisemitismus ulice či tzv. lidový antisemitismus, sycený především katolickou církví, lidový antisemitský humor. Antisemitismus měl schopnost prosáknout i do některých dobových slavností, např. na sokolský slet v roce 1926, dožínky ve Slaném v roce 1933 apod.

\footnotetext{
79 SOUKUPOVÁ, Velké a malé českožidovské př́běhy, s. 242, 245, 149.

80 Tamtéž, s. 135-136.

81 Tamtéž, s. 46 (Všeslovanská jednota v Praze), s. 48 (Štít republiky československé), s. 49 (Slovanská strana sociální), s. 51 (Štít národa), s. 60 (čeští fašisté).
} 
Místem koncentrace českoněmeckého antisemitismu se stala koncem dvacátých let vedle nacionalistických politických stran a turnerských spolků v západo- a severočeském pohraničí především pražská německá univerzita. I když Rélinkova výstava proběhla bez většího zájmu návštěvníků, předznamenala i nový nárůst antisemitismu od druhé poloviny dvacátých let minulého století a zejména od počátku let třicátých. V letech 1925-1926 podpořili, podobně jako vlivná národně demokratická strana, fašismus také agrárníci jako představitelé nejsilnější politické strany; naopak nejspolehlivější protiantisemitskou politickou stranou zůstávala sociální demokracie. Vyhroceně nacionalistické politické síly prorostly ovšem do vládní politické struktury až po Mnichovu (září 1938), přestože po květnových parlamentních volbách v roce 1935 získaly fašistické strany 23 mandátů, tedy více než polovinu křesel připadajících na nejvlivnější agrárníky. Pomnichovský antisemitismus čerpal nejen ze starších zdrojů, ale také z aktivit třicátých let, v nichž vznikla celá řada velmi vyhrocených (Vlajka, od roku 1936 spojena s Hnutím za nové Československo, Národní liga) i umírněnějších (Národní sjednocení, Národní fronta) antisemitských subjektů. Okrajové pozice vnitřně nejednotného antisemitského hnutí v masarykovském Československu lze však pravděpodobně nejvýmluvněji ilustrovat na faktu, že se českoslovenští antisemité nezúčastnili Světového kongresu antisemitů (1935). ${ }^{82}$

Zabýváme-li se iniciativou Svazu Čechů-židů v souvislosti s př́ípravou národnostního statutu před druhou světovou válkou, $\mathrm{z}$ dnešního pohledu má memorandum význam především jako jedinečný dokument o vysokých ambicích českožidovského hnutí při řešení národnostní situace v Československu v krizovém roce 1938. Současně dokumentuje i neochvějnou víru českožidovského hnutí v kvality a perspektivy československé demokracie i význam vlastního hnutí v rámci masarykovského Československa. Svým obsahem se memorandum nevymykalo tradici českožidovského myšlení (hodnocení asimilace, pohled na sionistickou ideologii a sionistické hnutí, odmítnutí národnostní samosprávy jako prostředku izolace židovského obyvatelstva apod.). Ovšem v českožidovském myšlení se projevovala i jistá stagnace v tom, že ani v atmosféře reálného ohrožení židovské menšiny nebylo českožidovské hnutí ochotné spolupracovat se sionistickým hnutím. Nejvýznamnějším dokladem demokratického základu českožidovského hnutí bylo jeho kultivované, pročeskoslovensky vyargumentované odmítnutí zásad proporcionality v oblasti podnikání, vědy a umění. Na tento politickým tlakem vynucený požadavek přistoupilo českožidovské hnutí až v období tzv. druhé republiky. ${ }^{83} \mathrm{~V}$ nejobecnější rovině však lze konstatovat, že cílem spolku bylo v nejisté situaci ukotvit postavení českožidovského asimilantského hnutí a usilovat o to, aby právní úprava v oblasti menšinové politiky i v rámci př́pravy národnostního statutu jeho význam nezpochybnila.

82 Souhrnně, s odkazy na četné prameny a další odbornou literaturu viz Tamtéž, s. 43-132.

83 V nové atmosféře se psalo o tzv. přeorientování, o nahrazení duševní práce prací manuální, viz Tamtéž, s. 187. 